\title{
Bintang Panjer Sore Sebagai Petunjuk Arah Kiblat Oleh Kelompok Nelayan "Mina Kencana" Desa Jambu Kecamatan Mlonggo Kabupaten Jepara
}

\author{
M. Ali Romdhon ${ }^{*}$, M. Arbisora Angkat ${ }^{2}$ \\ ${ }^{1}$ UIN Walisongo Semarang, ${ }^{2}$ STAIN Sultan Abdrurrahman Kepulauan Riau \\ 1*Email: aliromdhon@gmail.com
}

Abstract
Mina Kencana Fisherman Group use Panjer Sore Star as a guide
to the qibla direction at the sea. This star appears at sunset
around 17.30-18.00 WIB seen directly. Facing the star then
tilted to the right it means facing the qibla. Panjer Sore Star is
Venus. Venus cannot be used as a guide to the Qibla direction
by facing it directly because it has different azimuth with qibla
azimuth. In 2012, only June has the smallest azimuth difference
between Venus azimuth and qibla azimuth of Jambu Village,
about $0^{\circ} 40$ ' 31.48 ". So this method was inaccurate.

Artikel Info

Received:

29 Januari 2021

Revised:

23 Maret 2021

Accepted:

23 April 2021

Published:

08 Juni 2020

\section{Keywords : Panjer Sore Star, Qibla Direction.}

\begin{abstract}
Abstrak
Kelompok Nelayan Mina Kencana menggunakan Bintang Panjer Sore sebagai petunjuk arah kiblat ketika berada di laut. Bintang ini muncul pada waktu matahari terbenam sekitar pukul 17.30-18.00 WIB dilihat secara langsung. Dengan menghadap bintang itu lalu serong ke kanan berarti menghadap kiblat. Bintang Panjer Sore ternyata planet Venus. Venus tidak bisa digunakan sebagai petunjuk arah kiblat dengan menghadap langsung ke arahnya karena mempunyai azimuth yang berbeda dengan azimuth kiblat. Pada tahun 2012, hanya bulan Juni yang memiliki selisih azimuth terkecil antara azimuth Venus dan azimuth kiblat Desa Jambu, yakni $0^{\circ} 40^{\prime}$ 31,48'. Dengan demikian metode ini bisa dikatakan tidak akurat.
\end{abstract}

\section{Kata Kunci : Bintang Panjer Sore, Arah kiblat.}




\section{AL-MARSHAD: JURNAL ASTRONOMI ISLAM DAN ILMU-ILMU BERKAITAN \\ ISSN 2442-5729 (print) || ISSN 2598-2559 (online) \\ http://jurnal.umsu.ac.id/index.php/almarshad \\ DOI: //doi.org/10.30596/jam.v7i1.6216 || Vol. 7, No. 1 Juni 2021}

\section{A. Pendahuluan}

Untuk menentukan arah kiblat yang benar, hal pertama yang harus dilakukan adalah menentukan arah Utara Sejati. ${ }^{1} \mathrm{Hal}$ ini dilakukan untuk mempermudah kita dalam menentukan azimuth kiblat. Penentuan utara sejati bisa dilakukan dengan metode rasi bintang. Rasi bintang merupakan sekumpulan bintang yang berada di satu kawasan langit dan kelihatan berdekatan antara satu dengan yang lain.

Menurut International Astronomical Union (IAU), kubah langit dibagi menjadi delapan puluh delapan (88) kawasan rasi bintang. Bintang-bintang yang berada di satu kawasan yang sama adalah dalam satu rasi. Masyarakat dahulu telah menetapkan suatu rasi bintang mengikuti bentuk yang mudah mereka kenali secara pasti, seperti bentukbentuk binatang dan benda-benda. ${ }^{2}$

Dengan mengetahui rasi bintang tertentu, arah mata angin dan arah kiblat dari suatu tempat dapat ditentukan. Salah satu bintang yang dapat menunjukkan arah utara adalah rasi bintang ursa major dan ursa minor atau yang biasa dikenali dengan bintang kutub atau polaris. Garis yang ditarik dari tubuh ursa major ke ujung ekor

${ }^{1}$ Slamet Hambali, Menentukan Arah Kiblat Praktis (Semarang: Walisongo Press, 2010).

2 Slamet Hambali, Menentukan Arah Kiblat Praktis.

Slamet Hambali, Ilmu Falak I (Tentang Penentuan Awal Waktu Shalat Dan Penentuan Arah dari rasi ursa minor menunjukkan arah utara. ${ }^{3}$

Setelah mengetahui arah utara dari rasi bintang tersebut maka arah timur, selatan dan barat dapat diketahui dengan cara membuat garis perpotongan sehinga membentuk sudut siku-siku dengan garis utara-selatan yang telah ditentukan. Dengan demikian orang dapat memperkirakan dimana arah kiblat yang dicari. Selain itu ada juga rasi bintang yang langsung dapat digunakan untuk menentukan arah kiblat yaitu Rasi Bintang Orion. Pada rasi bintang tersebut terdapat tiga bintang yang berderet yaitu Mintaka, Alnilam dan Alnitak. Arah kiblar dapat diketahui dengan menarik garis khayal yang melalui ketiga bintang dalam arah timur-barat. Rasi Orion akan berada di langit Indonesia pada waktu shubuh bulan Juli di arah timur. Kemudian akan kelihatan lebih awal pada bulan Desember. Pada bulan Maret rasi Orion akan berada di sekitar zenit pada waktu Maghrib.

Kiblat yakni arah menuju Ka'bah di Makkah dan setiap muslim yang akan mengerjakan shalat diwajibkan menghadapkan badannya ke arah tersebut. Dimanapun ia berada ketika shalat maka wajib menghadap ke arah kiblat. ${ }^{4}$ Kata kiblat berasal

Kiblat Di Seluruh Dunia) (Semarang: Program Pascasarjana IAIN Walisongo, 2011).

${ }^{4}$ Arwin Juli Rakhmadi Butar-Butar, Pengantar Ilmu Falak Teori Dan Praktik (Depok: Rajawali Pers, 2018). 


\section{AL-MARSHAD: JURNAL ASTRONOMI ISLAM DAN ILMU-ILMU BERKAITAN \\ ISSN 2442-5729 (print) || ISSN 2598-2559 (online) \\ http://jurnal.umsu.ac.id/index.php/almarshad \\ DOI: //doi.org/10.30596/jam.v7i1.6216 || Vol. 7, No. 1 Juni 2021}

dari bahasa Arab yang artinya menghadap. ${ }^{5}$ Sedangkan kata kiblat dalam Al-Quran AlKarim mempunyai dua arti, yang pertama memiliki arti arah (kiblat) dan yang kedua memiliki arti tempat shalat. ${ }^{6}$ Kiblat juga bisa didefenisikan sebagai bangunan Ka'bah atau arah yang di tuju kaum muslimin dalam melaksanakan sebagian ibadah. ${ }^{7}$ Kiblat juga bisa diartikan sebagai arah atau jarak terdekat sepanjang lingkaran besar yang melewati ke $\mathrm{Ka}$ 'bah (Makkah) dengan tempat kota yang bersangkutan. ${ }^{8}$

Menghadap kiblat adalah salah satu di antara perkara yang menjadi syarat sahnya ibadah shalat. Ini sudah merupakan kesepakatan para ulama bahwa menghadap kiblat dalam melaksanakan shalat hukumnya adalah wajib, termasuk bagi seorang nelayan muslim. ${ }^{9}$ Bagi nelayan dalam Kelompok Nelayan "Mina Kencana" desa Jambu kecamatan Mlonggo kabupaten Jepara memiliki cara tersendiri dalam mengerjakan shalat di laut yang tidak sama dengan orang-orang yang

\footnotetext{
5 Ahmad Warson Munawir, Al-Munawir Kamus Arab-Indonesia (Surabaya: Pustaka Progressif, 1997).

6 Ahmad Izzuddin, Ilmu Falak Praktis (Metode Hisab-Rukyah Praktis Dan Solusi Permasalahannya) (Semarang: Komala Grafika, 2006).

7 Abdul Azis Dahlan. et al, Ensiklopedi Hukum Islam (Jakarta: PT Ichtiar Baru Van Hoeve, 1996).
}

mengerjakan shalat di darat. Kondisi di laut yang ada hanyalah air dan perahu atau kapal. Maka dari tu, pengetahuan tentang bintangbintang mutlak diperlukan untuk menentukan arah kiblat ketika akan shalat. ${ }^{10}$

Bintang Panjer Sore yang berada di arah barat dari desa Jambu ini menjadi acuan untuk menghadap kiblat. Yakni dengan menghadap bintang tersebut lalu serong ke kanan dan arah yang didapat itulah arah menuju Ka'bah di Makkah atau yang disebut arah kiblat. Kewajiban menghadap kiblat ini didasarkan pada firman Allah Swt. QS. AlBaqarah : 144

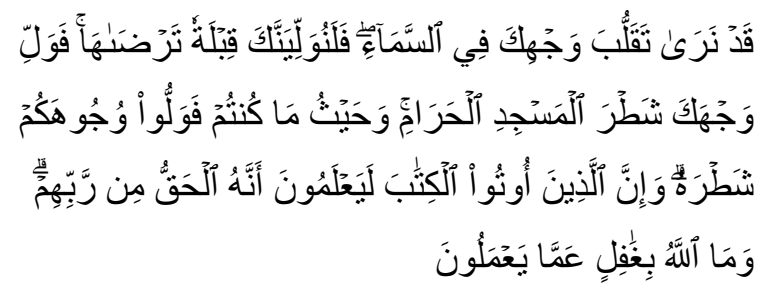

Artinya : "Sungguh Kami (sering) melihat mukamu menengadah ke langit, maka sungguh Kami akan memalingkan kamu ke kiblat yang kamu sukai. Palingkanlah mukamu ke arah Masjidil Haram. Dan dimana saja kamu berada, palingkanlah mukamu ke

\footnotetext{
${ }^{8}$ Muhyiddin Khazin, , Ilmu Falak (Dalam Teori Dan Praktik) (Yogyakarta: Buana Pustaka, 2004).

${ }^{9}$ M. Arbisora Angkat, 'Studi Analisis Penentuan Arah Kiblat Masjid Raya Al-Mashun Medan', ( $A L$ MARSHAD : Jurnal Astronomi Islam Dan Ilmu-Ilmu Berkaitan), 2.1 (2016), 34.

10 Wawancara dengan bapak Lakhiq., $26 \mathrm{Mei}$ 2012 Pukul 16:04 WIB.
} 


\section{AL-MARSHAD: JURNAL ASTRONOMI ISLAM DAN ILMU-ILMU BERKAITAN \\ ISSN 2442-5729 (print) || ISSN 2598-2559 (online) \\ http://jurnal.umsu.ac.id/index.php/almarshad \\ DOI: //doi.org/10.30596/jam.v7i1.6216 || Vol. 7, No. 1 Juni 2021}

arahnya. Dan sesunguhnya orang-orang (Yahudi dan Nasrani) yang diberi al-Kitab (Taurat dan Injil) memang mengetahui bahwa berpaling ke Masjidil Haram itu adalah benar dari Tuhan-NYA; dan Allah sekali-kali tidak lengah dari apa yang mereka kerjakan.” (QS. a-Baqarah : 144) ${ }^{11}$

Para nelayan meyakini bahwa menghadap ke barat dan serong ke kanan itulah arah menuju Ka'bah. Seperti apa yang disampaikan oleh para kiai sepuh mengenai tuntunan shalat memanglah benar adanya karena merekalah yang mulanya mengenalkan agama kepada para nelayan. Pengetahuan itupun diajarkan secara turun-temurun kepada generasi selanjutnya hingga sekarang. Pengetahuan tentang penggunaan bintang sebagai penunjuk arah kiblat ketika mengerjakan shalat di laut didapatkan dari generasi ke generasi yang bersumber dari tuntunan para kiai sepuh.

Berdasarkan keterangan diatas yang mengatakan bahwa penggunakan Bintang Panjer Sore dalam menentukan arah termasuk arah kiblat masih sebatas perkiraan saja dan kurang bisa dipertanggungjawabkan, maka perlu dilakukan penelitian lebih mendalam

11 Departemen Agama RI, Al-Quran Dan Terjemahnya (Bandung: CV Penerbit Jumanatul Ali Art, 2005). tentang Bintang Panjer Sore sebagai petunjuk arah kiblat oleh Kelompok Nelayan "Mina Kencana" Desa Jambu Kecamatan Mlonggo Kabupaten Jepara.

\section{Kelompok Nelayan "Mina Kencana"}

Desa Jambu Kecamatan Mlonggo Kabupaten Jepara berdiri pada tahun 1984. Menurut penuturan Shodiq, pendirian kelompok ini bermula dari kejadian yang dialami nelayan Desa Jambu Kecamatan Mlonggo Kabupaten Jepara. Beberapa nelayan mendapati jaringnya rusak karena sebuah alat pencari ikan yang ujungnya terbuat dari besi. Alat itu disebut dengan Jaring Cotok. Jaring Cotok merupakan alat pencari ikan yang digunakan oleh nelayan-nelayan yang menggunakan kapal. Alat ini berbentuk seperti ekrak (jawa). ${ }^{12}$

Penggunaannya dengan menariknya dengan tambang yang diikatkan di tiap tepinya dan ditarik darimana saja sejauh yang dikehendaki. Biasanya memang mengenai jaring nelayan lain. Jaring Cotok memang dilarang untuk digunakan karena bisa merugikan nelayan lainnya. ${ }^{13}$

Kelakuan tidak fair nelayan tersebut kemudian diketahui asalnya yakni dari daerah Jepara selatan, yaitu daerah Wedung dan sekitarnya. Selain itu, perbuatan yang sama

12 Wawancara dengan Bapak Shodiq, $16 \mathrm{Mei}$ 2012 Pukul 14.10 WIB.

${ }^{13}$ Wawancara dengan Bapak Zaini, '26 Mei 2012 Pukul 10.55 WIB'. 


\section{AL-MARSHAD: JURNAL ASTRONOMI ISLAM DAN ILMU-ILMU BERKAITAN \\ ISSN 2442-5729 (print) || ISSN 2598-2559 (online) \\ http://jurnal.umsu.ac.id/index.php/almarshad \\ DOI: //doi.org/10.30596/jam.v7i1.6216 || Vol. 7, No. 1 Juni 2021}

juga dilakukan nelayan dari daerah Jawa

Timur. Nelayan dari daerah Jawa Timur memang memiliki peralatan yang modern, menyesuaikan perkembangan zaman. Sehingga alat-alat seperti Jaring Cotok sangat mudah didapatkan.

Salah seorang nelayan, Shodiq, mendapati batas wilayah pencarian ikan untuk nelayan kecil yaitu 1-3 mil dilanggar oleh nelayan yang seharusnya batas melautnya di posisi lebih dari 3 mil, yakni kapal-kapal besar atau yang biasa disebut Korsin. Lampu-lampu yang digunakan Korsin untuk membatasi daerah peletakan jarring kemudian diseret menggunakan perahu hingga ke perkampungan. Ia lalu melaporkannya ke Kepolisian Sektor (Kapolsek) Mlonggo. Ia meminta agar segera diselesaikan, baik secara damai dan kekeluargaan maupun secara hukum.

Setelah kejadian itu, Shodiq beserta 20 nelayan lain bersepakat membentuk kelompok nelayan untuk bersama-sama menjaga wilayah laut demi kesejahteraan nelayan-nelayan kecil yang masih menggunakan peralatan sederhana. Kelompok tersebut diberi nama Kelompok Nelayan "Mina Kencana" dan bersekretariat di jalan TPI Mlonggo Km 1 Rw 06 desa Jambu kecamatan Mlonggo

\footnotetext{
${ }^{14}$ Wawancara dengan Bapak Shodiq.
}

kabupaten Jepara. ${ }^{14}$

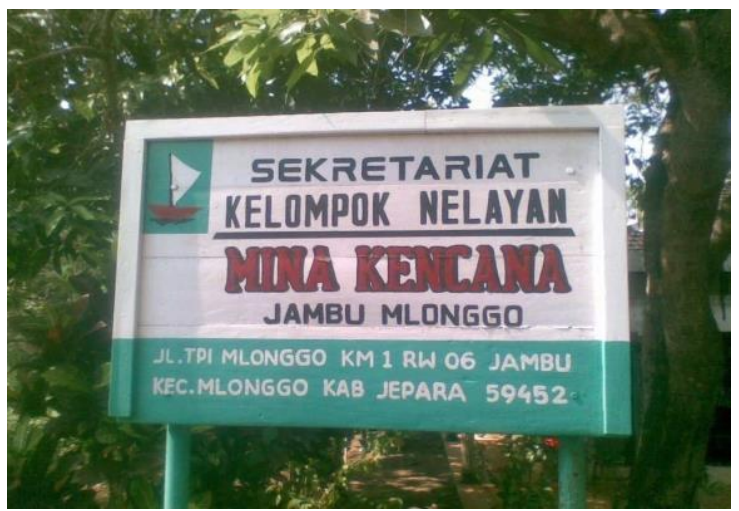

Gambar 1. Sekretariat Kelompok Nelayan "Mina Kencana"

Sejak berdiri pada tahun 1984, Kelompok Nelayan "Mina Kencana" Desa Jambu Kecamatan Mlonggo Kabupaten Jepara tidak terlalu mempersulit urusan kepengurusan. Hal ini ditunjukkan dengan struktur organisasi yang sangat sederhana. ${ }^{15}$

Para nelayan dalam Kelompok Nelayan "Mina Kencana" Desa Jambu Kecamatan Mlonggo Kabupaten Jepara menggunakan benda langit dan bekas gelombang untuk menunjukkan arah. Baik arah berangkat melaut maupun pulang.

Bekas gelombang air laut digunakan sebagai penunjuk arah dengan cara mengingatingat darimana datangnya angin yang menghembuskan air laut sehingga membentuk gelombang-gelombang kecil di sekitar perahu. Jadi, darimana berangkatnya nelayan bisa dijadikan pedoman untuk kembali pulang. Sedangkan untuk menentukan arah kiblat,

${ }^{15}$ Wawancara dengan Bapak Zaini. 


\section{AL-MARSHAD: JURNAL ASTRONOMI ISLAM DAN ILMU-ILMU BERKAITAN \\ ISSN 2442-5729 (print) || ISSN 2598-2559 (online) \\ http://jurnal.umsu.ac.id/index.php/almarshad \\ DOI: //doi.org/10.30596/jam.v7i1.6216 || Vol. 7, No. 1 Juni 2021}

nelayan menggunakan bintang sebagai penunjuk. Bintang yang digunakan yaitu Bintang Panjer Sore.

Bintang Panjer Sore adalah bintang yang bersinar paling terang diantara bintang-bintang lain di sekitarnya setelah matahari terbenam. Disebut Panjer Sore karena bintang tersebut akan tampak ketika memasuki sore hari. ${ }^{16}$

Posisi bintang ini berada di arah barat dari lokasi nelayan berangkat atau dari desa Jambu. Bintang tersebut akan mulai tampak setelah matahari terbenam di ufuk barat yakni antara pukul 17.30 WIB hingga pukul 18.00 WIB. Bintang ini dipakai sebagai acuan menghadap ke arah kiblat pada waktu menjalankan shalat maghrib dan sholat isya'. Yakni dengan cara melihatnya secara langsung tanpa menggunakan peralatan apapun.

Bintang ini digunakan oleh seluruh nelayan dalam kelompok nelayan "Mina Kencana" dan nelayan-nelayan di desa Jambu pada umumnya karena memang bintang ini merupakan bintang yang sangat terang dan mudah untuk dilihat. Selain itu posisinya di barat juga memudahkan nelayan untuk langsung menggunakannya sebagai penunjuk arah kiblat. Yakni dengan

\footnotetext{
${ }^{16}$ Wawancara dengan Bapak Sholikul Hadi, 16 Mei 2012 Pukul 14.10 WIB.
}

memandang atau mengarahkan badan ke arah bintang tersebut lalu menyerongkan badan ke kanan. $^{17}$

Arah yang didapat itulah arah menghadap ke kiblat. Hal ini didasarkan pada posisi pulau Jawa dimana Jepara termasuk di dalamnya berada di belahan bumi bagian selatan, sedangkan Ka'bah di Makkah berada di belahan bumi bagian utara. Jadi, menghadap kiblat tidak persis ke barat melainkan agak serong ke kanan.

Nelayan mengerjakan sholat di atas dek perahu dengan berpegangan atau bersandar pada tiang penyangga tenda atau lampu. Hal ini dilakukan karena tidak stabilnya kondisi perahu yang rentan sekali diterpa angin dan gelombang. Jika gelombang sedang tinggi, sholat dilakukan dengan duduk bersandar atau berpegangan pada penyanngga agar tidak terlempar ke laut. ${ }^{18}$

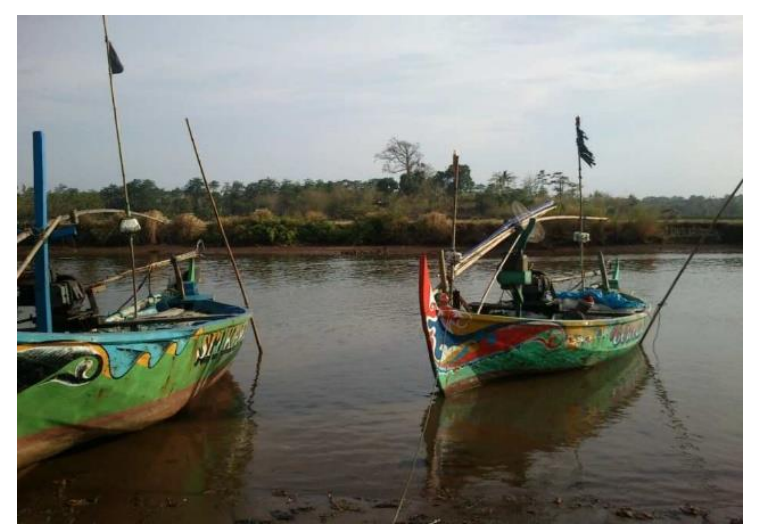

Gambar 2. Perahu yang digunakan oleh

\footnotetext{
${ }^{17}$ Wawancara dengan bapak Lakhiq. 26 Mei 2012 pukul 16:04 WIB., 26 Mei 2012 Pukul 16:04 WIB.

18 Wawancara dengan bapak Mugiono, 27 April 2012 Pukul 13:13 WIB.
} 


\section{Kelompok Nelayan "Mina Kencana"}

\section{B. Metode Penelitian}

Penelitian ini termasuk pada jenis penelitian lapangan (filed Research), ${ }^{19} \mathrm{di}$ mana penelitian ini bermaksud untuk mengetahui pemahaman, metode penentuan arah kiblat bagi Kelompok Nelayan Mina Kencana yang selama ini menggunakan Bintang Panjer Sore sebagai petunjuk arah kiblat ketika berada di laut. Penelitian ini dilakukan dengan analisis kualitatif ${ }^{20}$ yang dianalisis dan diklarifikasi terkait metode penentuan arah kiblat yang digunakan oleh Kelompok Nelayan Mina Kencana

Adapun metode pengumpulan data berupa observasi, wawancara dan dokumentasi. $^{21}$ Dalam menguji tingkat akurasi arah kiblat berdasarkan bintang Panjer Sore penulis menggunakan beberapa metode yakni dengan perhitungan azimuth kiblat dan qiblaocator.com. Teknisnya, penulis mengamati azimuth Venus tiap bulannya, lalu membandingkan hasilnya dengan perhitungan azimuth kiblat dan di cek di qiblalocator.com.

${ }^{19}$ Fahmi Fatwa Rosyadi Satria Hamdani and others, 'An Accuracy Test of Qibla Direction Measurement of Mosques and Prayer Rooms', 409.SoRes $2019 \quad$ (2020), $\quad 82-87$ <https://doi.org/10.2991/assehr.k.200225.018>.

20 A B D Karim Faiz, 'Moderasi Fiqh Penentuan Arah Kiblat: Akurasi Yang Fleksibel', Of Islamic Law 1, 1.1 (2020), 83-99.

\section{Hasil dan Pembahasan}

Bintang sebagai bagian dari ciptaan Tuhan sangat berarti bagi nelayan ketika akan melaut. Bintang-bintang digunakan sebagai acuan dalam menentukan arah saat berangkat serta pedoman ketika para nelayan akan pulang. Kelompok Nelayan "Mina Kencana" desa Jambu kecamatan Mlonggo kabupaten Jepara menggunakan bintang-bintang tidak hanya untuk menunjukkan arah. Akan tetapi bintang juga digunakan sebagai pedoman menghadap kiblat ketika shalat saat berada di tengah laut. Metode ini terbilang masih tradisional dan sederhana.

Penggunaan bintang sebagai penunjuk arah kiblat bagi nelayan dikatakan sebagai metode yang masih tradisional dikarenakan metode ini terlahir dari tradisi atau bisa dibilang turun temurun dari generasi ke generasi tanpa mengalami perubahan atau perkembangan yang berarti. Metode tersebut tergolong metode yang sederhana dikarenakan dalam mengaplikasikannya hanya mengandalkan mata telanjang tanpa alat bantu sebagaimana yang biasa dipakai untuk

21 Mohd. Kalam Daud and Muhammad Kamalussafir, 'Akurasi Arah Kiblat Komplek Pemakaman Ditinjau Menurut Kaidah Trigonometri (Studi Kasus Di Kecamatan Syiah Kuala Kota Banda Aceh)', SAMARAH: Jurnal Hukum Keluarga Dan Hukum Islam, 2.2 (2019), 502. 


\section{AL-MARSHAD: JURNAL ASTRONOMI ISLAM DAN ILMU-ILMU BERKAITAN \\ ISSN 2442-5729 (print) || ISSN 2598-2559 (online) \\ http://jurnal.umsu.ac.id/index.php/almarshad \\ DOI: //doi.org/10.30596/jam.v7i1.6216 || Vol. 7, No. 1 Juni 2021}

mengamati benda-benda langit pada umumnya seperti teleskop atau teropong bintang.

Hal ini disebabkan karena metode ini hanya bertumpu pada hasil pengamatan atau penglihatan dengan mata telanjang tanpa alat bantu. Selain itu, nelayan juga kurang memahami benda-benda langit yang muncul ketika mereka melaut. Baik benda langit berupa bintang ataupun planet. Nelayan juga kurang memahami lintasan atau orbit benda langit sehingga tidak tahu secara pasti kapan satu benda langit muncul, dimana dan sampai berapa lama benda langit tersebut bertahan di langit dan itu semua terbatas pada penglihatan nelayan.

Konsep yang dimiliki oleh Kelompok Nelayan "Mina Kencana” ini mengacu pada hasil observasi dan kebiasaan-kebiasaan yang dijadikan pedoman semata. Dalam apikasinya para nelayan hanya memperkirakan waktu munculnya bintang tertentu, berapa lama bintang tersebut dapat ditangkap indera penglihatan. Bintang yang dijadikan penunjuk arah kiblat oleh nelayan yakni bintang Panjer Sore merupakan bintang yang muncul paling terang di belahan

${ }^{22}$ Wawancara dengan Bapak Sholikul Hadi.

${ }^{23}$ David Morrison and Tobias Owen, The Planetary System (Canada : Addison Wesley, 1988), h. 228. langit sebelah barat setelah matahari terbenam hinga sekitar 2 jam atau kurang lebih mulai pukul 18.00 WIB hingga 20.00 WIB. $^{22}$

Ketidakpastian waktu munculnya bintang Panjer Sore, pada bulan apa saja bintang tersebut tidak muncul pada waktu yang biasa yakni sore hari, tersebutlah yang tentu sangat mempengaruhi tingkat akurasi metode itu sendiri. Selain itu, konsep penggunaan bintang Panjer Sore sebagai penunjuk arah kiblat memang tidak sama dengan kajian-kajian yang sudah ada mengenai penggunaan bintang sebagai pedoman menentukan arah kiblat yakni menggunakan rasi bintang Orion walaupun konsep tersebut juga merupakan perkiraan dan belum bisa dipastikan akurasinya.

Berdasarkan analisa penulis terhadap konsep penggunaan bintang sebagai penunjuk arah kiblat nelayan, dapat ditemukan bahwa bintang yang digunakan nelayan sebagai penunjuk arah kiblat bukan merupakan bintang melainkan sebuah planet yakni planet Venus. Venus merupakan planet yang paling dekat dengan bumi. ${ }^{2324}$ Bisa diketahui bahwa itu adalah Venus berdasarkan pengamatan penulis dan di cek di software Starrynight Backyard ESD dan Starrynight Pro Plus 6 dengan koordinat lokasi yang sama.

24 David Morrison and Tobias Owen, The Planetary System (Canada: Addison Wesley, 1988). 


\section{AL-MARSHAD: JURNAL ASTRONOMI ISLAM DAN ILMU-ILMU BERKAITAN \\ ISSN 2442-5729 (print) || ISSN 2598-2559 (online) \\ http://jurnal.umsu.ac.id/index.php/almarshad \\ DOI: //doi.org/10.30596/jam.v7i1.6216 || Vol. 7, No. 1 Juni 2021}

Pengamatan dilakukan penulis pada 26 Mei 2012 di pesisir pantai desa Jambu kecamatan Mlonggo kabupaten Jepara. Hal ini berdasarkan saran dari ketua Kelompok Nelayan "Mina Kencana” Bapak Sholikul.

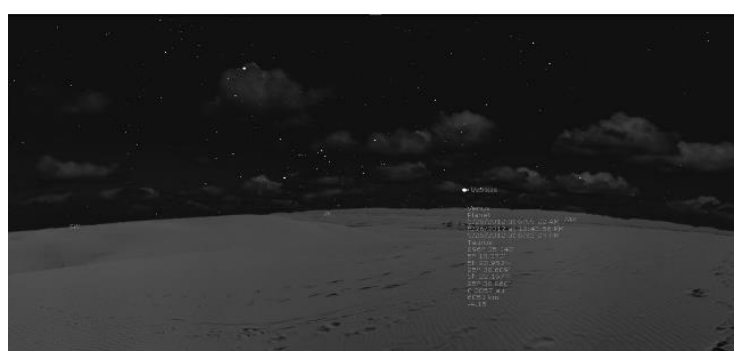

Gambar 3. Bintang Panjer Sore dalam Starrynight Pro Plus 6

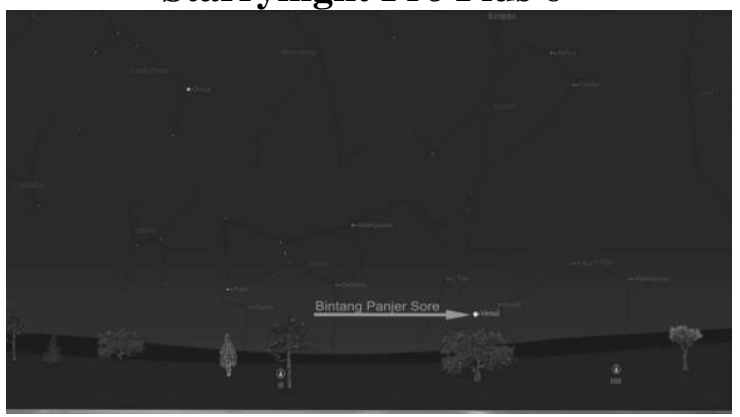

Gambar 4. Bintang Panjer Sore Dalam Starrynight Backyard Esd

Dua gambar di atas yakni Gambar

IV.1 dan Gambar IV.2 menunjukkan kemunculan planet Venus pada 26 Mei 2012 pukul 18.06 WIB atau yang oleh nelayan disebut bintang Panjer Sore.

\section{Akurasi Penggunaan Bintang} Panjer Sebagai Penunjuk Arah Kiblat

Dalam menguji tingkat akurasi arah kiblat berdasarkan bintang Panjer Sore penulis menggunakan beberapa metode yakni dengan perhitungan azimuth kiblat dan qiblaocator.com. Teknisnya, penulis mengamati azimuth Venus tiap bulannya, lalu membandingkan hasilnya dengan perhitungan azimuth kiblat dan di cek di qiblalocator.com.

Penulis membuat tiga titik lokasi perhitungan arah kiblat di sekitar pantai desa Jambu kecamatan Mlonggo kabupaten Jepara. Titik 1 berada di kordinat $-6^{\circ} 31^{\prime} 38^{\prime \prime}$ LS dan $110^{\circ} 40^{\prime} 53,6$ " BT. Titik 2 berada di kordinat $-6^{\circ} 31^{\prime} 18,8^{\prime \prime}$ LS dan $110^{\circ} 40^{\prime}$ 59” BT. Titik 3 berada di kordinat $-6^{\circ} 30^{\prime}$ 17,3" LS dan $110^{\circ} 39^{\prime} 55,1^{\prime}$ BT. Data lintang dan bujur lokasi didapatkan dari data GPS yang ter-instal di handphone Sony Ericsson CK15I txt Pro. Lokasinya berada di pesisir pantai desa Jambu kecamatan Mlonggo kabupaten Jepara dan diambil pada 16 November 2012. Untuk mendapatkan arah kiblat suatu tempat maka data yang diperlukan adalah sebagai berikut :

a. Lintang $(\varphi)$ Makkah : $21^{\circ} 25^{\prime} 21.04^{\prime \prime} \mathrm{LU}$

b. Bujur $(\lambda)$ Makkah : 39 49'34.33” BT

c. Lintang tempat $1:-6^{\circ} 31^{\prime} 38^{\prime \prime} \mathrm{LS}$

d. Lintang tempat 2 : $-6^{\circ} 31^{\prime} 18,8$ " LS

e. Lintang tempat $3:-6^{\circ} 30^{\prime} 17,3$ ” LS

f. Bujur tempat $1: 110^{\circ} 40^{\prime} 53,6^{\prime \prime}$ BT

g. Bujur tempat $2: 110^{\circ} 40^{\prime} 59^{\prime \prime}$ BT

h. Bujur tempat $3: 110^{\circ} 39^{\prime} 55,1^{\prime \prime}$ BT

Dengan menggunakan rumus sederhana berikut :

$\operatorname{Cotan} B=\tan \varphi^{k} x \cos \varphi^{x} \div \sin C-\sin \varphi^{x} \div \tan C$

B : adalah arah kiblat. Jika hasil perhitungan B 


\section{AL-MARSHAD: JURNAL ASTRONOMI ISLAM DAN ILMU-ILMU BERKAITAN \\ ISSN 2442-5729 (print) || ISSN 2598-2559 (online) \\ http://jurnal.umsu.ac.id/index.php/almarshad \\ DOI: //doi.org/10.30596/jam.v7i1.6216 || Vol. 7, No. 1 Juni 2021}

positif maka arah kiblat terhitung dari titik

Utara. Namun jika hasil perhitungan B negatif maka arah kiblat terhitung dari titik Selatan.

$\varphi^{\mathrm{k}}$ : adalah lintang Ka'bah yaitu $21^{\circ} 25^{\prime}$

21.04” LU

$\varphi^{\mathrm{x}}:$ adalah lintang tempat yang akan diukur arah kiblatnya (desa jambu)

C : adaah jarak bujur, yaitu jarak bujur antara Ka'bah dengan bujur tempat yang akan diukur arah kiblatnya.

Sehingga didapatlah hasil azimuth kiblat dari 3 titik lokasi berikut :

a. Azimuth kiblat desa Jambu Titik $1: \mathbf{2 9 4}^{\circ}$

\section{9' 38" UTSB}

Jika dilihat dalam qiblalocator.com adalah sebagai berikut :
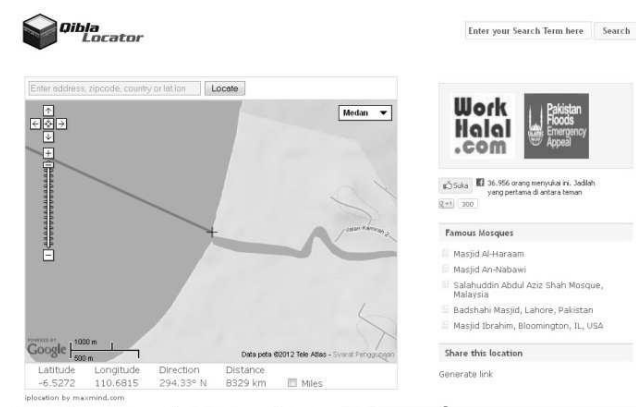

Setelah mengetahui arah kiblat desa Jambu, maka untuk selanjutnya adalah mengetahui arah kiblat menggunakan bintang Panjer Sore atau planet Venus. Penulis menggunakan data dari software Starrynight
Gambar 5. Arah Kiblat desa Jambu Titik 1 dari qiblalocator.com

b. Azimuth kiblat desa Jambu Titik $2=\mathbf{2 9 4}^{\circ}$

\section{9' 32" UTSB}

Jika dilihat dalam qiblalocator.com adalah sebagai berikut :

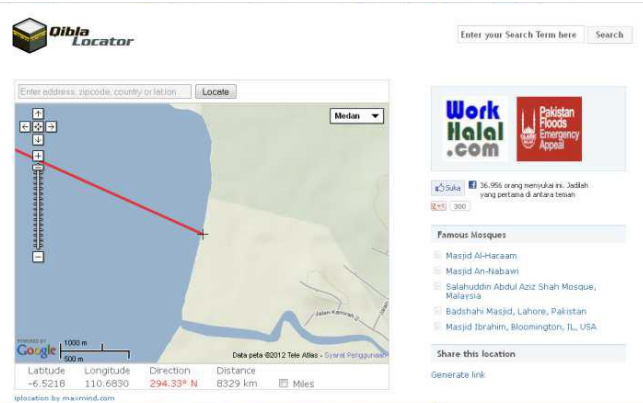

Gambar 6. Arah Kiblat desa Jambu Titik 2 dari qiblalocator.com

c. Azimuth kiblat desa Jambu Titik 3 : 294${ }^{\circ}$

\section{9'31,1" UTSB}

Jika dilihat dalam qiblalocator.com adalah sebagai berikut :
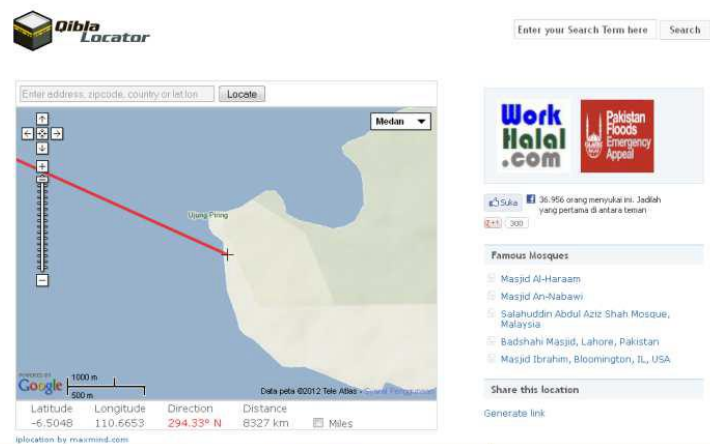

Gambar 7. Arah Kiblat desa Jambu Titik 3 dari qiblalocator.com

Pro Plus 6 agar lebih detil. Berikut ini data Venus selama satu tahun 2012 : yang ditunjukkan dalam Tabel 1. Dibawah ini 


\section{AL-MARSHAD: JURNAL ASTRONOMI ISLAM DAN ILMU-ILMU BERKAITAN \\ ISSN 2442-5729 (print) || ISSN 2598-2559 (online) \\ http://jurnal.umsu.ac.id/index.php/almarshad \\ DOI: //doi.org/10.30596/jam.v7i1.6216 || Vol. 7, No. 1 Juni 2021}

Tabel. 1 Data Azimut Venus, Ketinggian (Altitude) dan Deklinasi

\begin{tabular}{|c|c|c|c|c|}
\hline \multirow[b]{2}{*}{ No } & \multirow[b]{2}{*}{ Bulan } & \multicolumn{3}{|c|}{ Data Venus } \\
\hline & & Azimut Venus & Altitude & Deklinasi \\
\hline 1 & Januari & $252^{\circ} 53^{\prime} 57,1^{\prime \prime}$ & $23^{\circ} 1^{\prime} 52,68^{\prime \prime}$ & $-18^{\circ} 15^{\prime} 11,22^{\prime \prime}$ \\
\hline 2 & Februari & $268^{\circ} 52^{\prime} 45,7^{\prime \prime}$ & $27^{\circ} 12^{\prime} 51,6 "$ & $-3^{\circ} 59^{\prime} 57,6^{\prime \prime}$ \\
\hline 3 & Maret & $285^{\circ} 42^{\prime} 49,8^{\prime \prime}$ & $26^{\circ} 28^{\prime} 42^{\prime \prime}$ & $10^{\circ} 53^{\prime} 27,24^{\prime \prime}$ \\
\hline 4 & April & $299^{\circ} 0{ }^{\prime} 6,84^{\prime \prime}$ & $23^{\circ} 56^{\prime} 37,26^{\prime \prime}$ & $23^{\circ} 7^{\prime} 3,78^{\prime \prime}$ \\
\hline 5 & Mei & $302^{\circ} 6^{\prime} 35,94^{\prime \prime}$ & $18^{\circ} 1 ' 45,96^{\prime \prime}$ & $27^{\circ} 46^{\prime} 50,16^{\prime \prime}$ \\
\hline 6 & Juni & $295^{\circ} 0^{\prime} 9,48^{\prime \prime}$ & $4^{\circ} 42^{\prime} 24,18^{\prime \prime}$ & $24^{\circ} 10^{\prime} 17,7^{\prime \prime}$ \\
\hline 7 & Juli & $286^{\circ} 37^{\prime} 23,1^{\prime \prime}$ & $-32^{\circ} 31^{\prime} 19,38^{\prime \prime}$ & $17^{\circ} 29^{\prime} 52,56^{\prime \prime}$ \\
\hline 8 & Agustus & $290^{\circ} 41^{\prime} 21^{\prime \prime}$ & $-44^{\circ} 48^{\prime} 23,34 \prime$ & $19^{\circ} 12^{\prime} 33,84^{\prime \prime}$ \\
\hline 9 & September & $290^{\circ} 34^{\prime} 9,96^{\prime \prime}$ & $-43^{\circ} 55^{\prime} 26,76^{\prime \prime}$ & $19^{\circ} 16^{\prime} 40,92^{\prime \prime}$ \\
\hline 10 & Oktober & $280^{\circ} 47^{\prime} 52,3^{\prime \prime}$ & $-40^{\circ} 22^{\prime} 0,9^{\prime \prime}$ & $12^{\circ} 26^{\prime} 4,5^{\prime \prime}$ \\
\hline 11 & November & $264^{\circ} 50^{\prime} 2,1^{\prime \prime}$ & $-35^{\circ} 27^{\prime} 8,58^{\prime \prime}$ & $-0^{\circ} 24^{\prime} 13,44^{\prime \prime}$ \\
\hline 12 & Desember & $250^{\circ} 43^{\prime} 15^{\prime \prime}$ & $-27^{\circ} 44^{\prime} 52,02^{\prime \prime}$ & $-13^{\circ} 44^{\prime} 15,36^{\prime \prime}$ \\
\hline
\end{tabular}

yang ditunjukkan oleh Tabel 2. Dibawah ini :

Tabel. 2. Data Selisih Azimut Kiblat \& Azimut Venus, Ketinggian (Altitude) dan Deklinasi

\begin{tabular}{|c|c|c|c|c|}
\hline \multirow[b]{2}{*}{ No } & \multirow[b]{2}{*}{ Bulan } & \multicolumn{3}{|c|}{ Data Venus } \\
\hline & & Selisih Azimut & Altitude & Dekinasi \\
\hline 1 & Januari & $41^{\circ} 25^{\prime} 40,9^{\prime \prime}$ & $23^{\circ} 1^{\prime} 52,68^{\prime \prime}$ & $-18^{\circ} 15^{\prime} 11,22^{\prime \prime}$ \\
\hline 2 & Februari & $25^{\circ} 26^{\prime} 52,3^{\prime \prime}$ & $27^{\circ} 12^{\prime} 51,6^{\prime \prime}$ & $-3^{\circ} 59^{\prime} 57,6^{\prime \prime}$ \\
\hline 3 & Maret & $8^{\circ} 36^{\prime} 48,2^{\prime \prime}$ & $26^{\circ} 28^{\prime} 42^{\prime \prime}$ & $10^{\circ} 53^{\prime} 27,24^{\prime \prime}$ \\
\hline 4 & April & $4^{\circ} 40^{\prime} 28,84^{\prime \prime}$ & $23^{\circ} 56^{\prime} 37,26^{\prime \prime}$ & $23^{\circ} 7^{\prime} 3,78^{\prime \prime}$ \\
\hline 5 & Mei & $7^{\circ} 46^{\prime} 57,94^{\prime \prime}$ & $18^{\circ} 1^{\prime} 45,96^{\prime \prime}$ & $27^{\circ} 46^{\prime} 50,16^{\prime \prime}$ \\
\hline 6 & Juni & $0^{\circ} 40^{\prime} 31,48^{\prime \prime}$ & $4^{\circ} 42^{\prime} 24,18^{\prime \prime}$ & $24^{\circ} 10^{\prime} 17,7^{\prime \prime}$ \\
\hline 7 & Juli & $7^{\circ} 42^{\prime} 14,9$ '” & $-32^{\circ} 31^{\prime} 19,38^{\prime \prime}$ & $17^{\circ} 29^{\prime} 52,56^{\prime \prime}$ \\
\hline 8 & Agustus & $03^{\circ} 38^{\prime} 17^{\prime \prime}$ & $-44^{\circ} 48^{\prime} 23,34^{\prime \prime}$ & $19^{\circ} 12^{\prime} 33,84^{\prime \prime}$ \\
\hline 9 & September & $3^{\circ} 45^{\prime} 28,04^{\prime \prime}$ & $-43^{\circ} 55^{\prime} 26,76^{\prime \prime}$ & $19^{\circ} 16^{\prime} 40,92^{\prime \prime}$ \\
\hline 10 & Oktober & $13^{\circ} 31^{\prime} 45,7^{\prime \prime}$ & $-40^{\circ} 22^{\prime} 0,9^{\prime \prime}$ & $12^{\circ} 26^{\prime} 4,5^{\prime \prime}$ \\
\hline 11 & November & $29^{\circ} 29^{\prime} 35,9^{\prime \prime}$ & $-35^{\circ} 27^{\prime} 8,58^{\prime \prime}$ & $-0^{\circ} 24^{\prime} 13,44^{\prime \prime}$ \\
\hline 12 & Desember & $43^{\circ} 36^{\prime} 23^{\prime \prime}$ & $-27^{\circ} 44^{\prime} 52,02^{\prime \prime}$ & $-13^{\circ} 44^{\prime} 15,36^{\prime \prime}$ \\
\hline
\end{tabular}

Setelah mengamati data dalam Tabel

2. di atas, dalam satu tahun ada dua bagian antara kemungkinan bisa dilihatnya bintang Panjer Sore (Venus) dan tidaknya. Pertama, mulai Januari hingga Juni, Venus pada jam 17.35 WIB memiliki ketinggian berkisar antara $4^{\circ}-27^{\circ}$. Pada bulan-bulan para nelayan. Akan tetapi, selisih antara azimuth Venus dan azimuth kiblat sangatlah jauh. Bahkan selisih terjauh hingga mencapai $43^{\circ} 36^{\prime} 23^{\prime}$ " yakni pada awal bulan Desember.

Namun pada awal bulan Juni, selisih 


\section{AL-MARSHAD: JURNAL ASTRONOMI ISLAM DAN ILMU-ILMU BERKAITAN \\ ISSN 2442-5729 (print) || ISSN 2598-2559 (online) \\ http://jurnal.umsu.ac.id/index.php/almarshad \\ DOI: //doi.org/10.30596/jam.v7i1.6216 || Vol. 7, No. 1 Juni 2021}

antara azimuth Venus dan azimuth kiblat hanya $0^{\circ} 40^{\prime} 31,48^{\prime \prime}$ (1 Juni), 0²6’09,93” (2 Juni), $0^{\circ} 43 ’ 16,71$ ” (3 Juni). Menurut penulis, hanya pada awal bulan Juni inilah bintang Panjer Sore bisa digunakan sebagai penunjuk arah kiblat yang lumayan mendekati arah yang tepat dengan selisih terkecil dan dengan ketinggian yang memungkinkan untuk bisa dilihat.

Kedua, bulan-bulan dimana Venus sudah tenggelam di barat lebih dulu dibandingkan matahari yakni terjadi pada bulan Juli hingga Desember 2012. Bahkan ketinggian terendah mencapai minus (-) $44^{\circ}$ 48' 23,34”. Pada bulan-bulan ini nelayan benar-benar tidak bisa melihat bintang Panjer Sore pada waktu sore hari. Posisi planet selalu berubah, jika memang ingin menggunakan bintang sebagai penunjuk arah kiblat, maka sebaiknya mencari bintang yang terang dengan posisi di atas zenith Ka'bah. ${ }^{25}$

Dalam konsepnya, metode penggunaan bintang Panjer Sore atau planet Venus sebagai penunjuk arah kiblat tidak hanya bisa digunakan oleh para nelayan ketika melaut, namun bisa digunakan pula ketika di darat. Misalnya, untuk pengukuran masjid atau mushalla. Bisa juga digunakan untuk keperluan mushalla pribadi di rumah.
Penggunaannya tentu harus disertai koreksi-koreksi yang diperlukan. Untuk tanggal 1 Juni misalnya, bintang Panjer Sore berada di azimuth $295^{\circ}$ 0' 9,48" UTSB sedangkan azimuth kiblatnya berada pada 294 19' 38" UTSB.

Jadi jika ingin menentukan arah kiblat pada tanggal 1 Juni menggunakan bintang Panjer Sore harus mengurangi arah sebesar $0^{\circ} 40^{\prime} 31,48 "$ dari arah menuju bintang tersebut atau planet Venus.

Berikut ini adalah gambar sebagai ilustrasi adanya koreksi terhadap arah yang dituju ketika menggunakan bintang Panjer Sore sebagai acuan penunjuk arah kiblat.

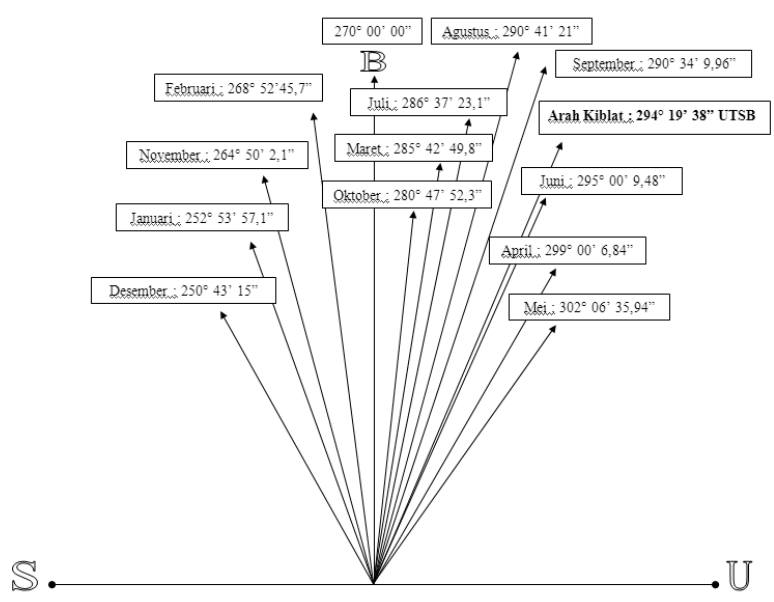

Gambar 7. Gambar Azimuth Kiblat \& Azimuth Bintang Panjer Sore (Venus)

\section{Penutup}

Berdasarkan pembahasan dan analisa yang penulis jelaskan di atas, dapat disimpulkan bahwa :

\footnotetext{
${ }^{25}$ Wawancara dengan Thomas Djamaluddin, 23 November 2012.
} 


\section{AL-MARSHAD: JURNAL ASTRONOMI ISLAM DAN ILMU-ILMU BERKAITAN \\ ISSN 2442-5729 (print) || ISSN 2598-2559 (online) \\ http://jurnal.umsu.ac.id/index.php/almarshad \\ DOI: //doi.org/10.30596/jam.v7i1.6216 || Vol. 7, No. 1 Juni 2021}

1. Nelayan dalam Kelompok Nelayan "Mina Kencana" desa jambu kecamatan Mlonggo kabupaten Jepara menggunakan Bintang Panjer Sore untuk digunakan sebagai penunjuk arah kiblat ketika berada di laut. Bintang Panjer Sore mulai muncul pada waktu matahari terbenam sekitar pukul 17.30-18.00 WIB. Penggunaannya yakni dengan melihat secara langsung tanpa alat bantu teropong atau teleskop. Ketika mengerjakan shalat, dengan menghadap bintang tersebut lalu serong ke kanan berarti menghadap ke kiblat.

2. Bintang Panjer Sore merupakan sebuah planet yakni planet Venus. Bintang Panjer Sore tidak bisa digunakan sebagai petunjuk arah kiblat dengan menghadap langsung ke arahnya karena mempunyai azimuth yang berbeda dengan azimuth kiblat. Dalam satu tahun 2012 hanya bulan Juni yang selisih azimuth Venus dan arah kiblat dari desa Jambu kecil. Bahkan itu terjadi pada tanggal 1,2,3 Juni saja yakni dengan nilai $0^{\circ} 40^{\prime} 31,48^{\prime \prime}$ (1 Juni), $0^{\circ}$ 26' 09,93” (2 Juni), $0^{\circ} 43$ ' 16,71" (3 Juni). Metode ini bisa digunakan namun harus disertai dengan koreksi-koreksi yang disesuaikan dengan perbedaan azimuth Venus dan azimuth kiblat desa Jambu. Dengan demikian konsep ini bisa dikatakan tidak akurat. 
M. Arbisora Angkat, 'Studi Analisis Penentuan Arah Kiblat Masjid Raya Al-

Mashun Medan', (AL-MARSHAD:

Jurnal Astronomi Islam Dan Ilmu-Ilmu

Berkaitan), 2.1 (2016), 34

Mohd. Kalam Daud and Muhammad

Kamalussafir, 'Akurasi Arah Kiblat

Komplek Pemakaman Ditinjau Menurut

Kaidah Trigonometri (Studi Kasus Di

Kecamatan Syiah Kuala Kota Banda

Aceh)', SAMARAH: Jurnal Hukum

Keluarga Dan Hukum Islam, 2.2 (2019),

502

Muhyiddin Khazin, , Ilmu Falak (Dalam

Teori Dan Praktik) (Yogyakarta: Buana

Pustaka, 2004)

Slamet Hambali, Ilmu Falak I (Tentang

Penentuan Awal Waktu Shalat Dan

Penentuan Arah Kiblat Di Seluruh

Dunia) (Semarang: Program

Pascasarjana IAIN Walisongo, 2011)

—, Menentukan Arah Kiblat Praktis

(Semarang: Walisongo Press, 2010)

Wawancara dengan bapak Lakhiq., $26 \mathrm{Mei}$

2012 Pukul 16:04 WIB

Wawancara dengan bapak Lakhiq. 26 Mei

2012 pukul 16:04 WIB., 26 Mei 2012

Pukul 16:04 WIB

Wawancara dengan bapak Mugiono, 27 April

2012 Pukul 13:13 WIB

Wawancara dengan Bapak Shodiq, $16 \mathrm{Mei}$

2012 Pukul 14.10 WIB
Wawancara dengan Bapak Sholikul Hadi, 16 Mei 2012 Pukul 14.10 WIB

Wawancara dengan Bapak Zaini, '26 Mei 2012 Pukul 10.55 WIB'

Wawancara dengan Thomas Djamaluddin, 23

November 2012 